\title{
Enhancement of Secretagogue-induced Phosphoinositide Turnover and Amylase Secretion by Bile Acids in Isolated Rat Pancreatic Acini
}

\author{
Yoshifumi Takeyama,* Hiroyuki Nakanishi," Harumasa Ohyanagi,* Yoichi Saitoh,“ Kozo Kaibuchi, and Yoshimi Takai \\ Departments of Biochemistry and Surgery (Division 1),* Kobe University School of Medicine, Kobe 650, Japan
}

\begin{abstract}
Small amounts (0.1-0.5 $\mathrm{mM})$ of deoxycholate enhanced amylase secretion, which had been induced by submaximal doses of carbachol or cholecystokinin octapeptide, without affecting the maximal levels of these reactions from isolated rat pancreatic acini. Deoxycholate alone did not induce these reactions. The other bile acids such as cholate, chenodeoxycholate, ursodeoxycholate, and taurocholate were also active. Under the similar conditions, deoxycholate enhanced the secretagogue-induced diacylglycerol formation that was derived mainly from the phospholipase C-mediated hydrolysis of phosphatidylinositol and phosphatidylinositol-4-monophosphate. Deoxycholate did not enhance the secretagogue-induced hydrolysis of phosphatidylinositol-4,5-bisphosphate or $\mathrm{Ca}^{2+}$ mobilization. Deoxycholate did not affect amylase secretion, which was induced by the simultaneous addition of protein kinase $\mathrm{C}$-activating 12- $\mathrm{O}$-tetradecanoylphorbol-13-acetate and $\mathrm{Ca}^{2+}$ ionophore ionomycin. Since diacylglycerol and $\mathrm{Ca}^{2+}$ may be responsible for the secretagogueinduced amylase secretion, our results indicate that small amounts of bile acids increase the sensitivity to the secretagogue of diacylglycerol formation and subsequent activation of protein kinase $C$, and thereby enhance amylase secretion from pancreatic acini.
\end{abstract}

\section{Introduction}

Biliary pancreatitis is the disease form produced by reflux of bile acids into the pancreatic duct systems and is associated with coagulation necrosis of ductal system epithelia and neighboring acinar cell complexes (for a review, see reference 1). Similar pancreatitis can be elicited experimentally by the injection of deoxycholate (DCA), ${ }^{1}$ one of the secondary bile acids, into the pancreatic duct systems (2-5). Numerous studies on biliary pancreatitis have been done, and hypersecretion of digestive enzymes, such as proteases and lipases, from pancreatic acinar

Address correspondence to Dr. Takai at the Department of Biochemistry, Kobe University School of Medicine, Kobe 650, Japan.

Received for publication 14 November 1985 and in revised form 6 August 1986.

1. Abbreviations used in this paper: $\left[\mathrm{Ca}^{2+}\right] \mathrm{i}$, cytoplasmic free $\mathrm{Ca}^{2+}$ concentration; $\mathrm{CCK}_{8}$, cholecystokinin octapeptide; DCA, deoxycholate; DG, diacylglycerol; IP, inositol-monophosphate; $\mathrm{IP}_{\mathbf{2}}$, inositol-bisphosphate; $\mathrm{IP}_{3}$, inositol-trisphosphate; OAG, 1-oleoyl-2-acetylglycerol; PI, phosphatidylinositol; PIP, phosphatidylinositol-4-monophosphate; PIP $_{2}$, phosphatidylinositol-4,5-bisphosphate; TPA, 12-O-tetradecanoylphorbol13-acetate.

J. Clin. Invest.

(C) The American Society for Clinical Investigation, Inc.

$0021-9738 / 86 / 12 / 1604 / 08 \quad \$ 1,00$

Volume 78, December 1986, 1604-1611 cells has been suggested to be one of the causes for the generation of this disease (6).

The secretion of the digestive enzymes from exocrine pancreas is controlled by muscarinic action of acetylcholine, cholecystokinin octapeptide $\left(\mathrm{CCK}_{8}\right)$, gastrin, and other secretagogues (for a review, see reference 7). Recently, the modes of action of many secretagogues, including acetylcholine and $\mathrm{CCK}_{8}$, have been investigated extensively. It has been clarified that diacylglycerol (DG) and $\mathrm{Ca}^{2+}$ may serve as second messengers for many secretagogues through the activation of protein kinase $C$, and $\mathrm{Ca}^{2+}$ receptors such as calmodulin, respectively, and that both DG and $\mathrm{Ca}^{2+}$ are essential and synergistically effective for eliciting release reactions (for reviews, see references 8 and 9). DG is derived from the hydrolysis of phosphoinositides including phosphatidylinositol-4,5-bisphosphate $\left(\mathrm{PIP}_{2}\right)$, phosphatidylinositol-4-monophosphate (PIP), and phosphatidylinositol (PI) by the action of phospholipase $\mathrm{C}$ in a manner linked to the receptors of the secretagogues. Although the regulatory mechanism of $\mathrm{Ca}^{2+}$ influx through plasma membrane $\mathrm{Ca}^{2+}$ channels is not known, it has been clarified that $\mathrm{Ca}^{2+}$ mobilization from intracellular stores to the cytoplasm is triggered by inositol-trisphosphate $\left(\mathrm{IP}_{3}\right)$, which is another product of the hydrolysis of $\operatorname{PIP}_{2}(9)$. Evidence has also been obtained that the simultaneous addition of membrane-permeable protein kinase $\mathrm{C}$-activating agents, such as 1oleoyl-2-acetylglycerol (OAG) and 12-O-tetradecanoylphorbol13-acetate (TPA), and $\mathrm{Ca}^{2+}$-mobilizing agents, such as $\mathrm{Ca}^{2+}$ ionophores A23187 and ionomycin, induces release reactions from various types of secretory cells (10-16). In pancreatic acini, it has been demonstrated that (a) Acetylcholine or $\mathrm{CCK}_{8}$ stimulates the formation of $\mathrm{DG}$ and $\mathrm{IP}_{3}$ from phosphoinositide turnover in exocrine pancreas (17-20); (b) Incubation with $\mathrm{IP}_{3}$ of isolated rat pancreatic acinar cells permeabilized by washing the cells with a nominally $\mathrm{Ca}^{2+}$-free solution stimulates the elevation of cytoplasmic free $\mathrm{Ca}^{2+}$ concentration $\left(\left[\mathrm{Ca}^{2+}\right] \mathrm{i}\right)(21)$; and (c) OAG or TPA synergistically enhances amylase secretion in the presence of $\mathrm{Ca}^{2+}$ ionophore (16). On the basis of these three lines of evidence, it is currently considered that both DG-protein kinase $\mathrm{C}$ and $\mathrm{IP}_{3}-\mathrm{Ca}^{2+}$ systems are involved in acetylcholine- or $\mathrm{CCK}_{8-}$ induced secretion in pancreatic acini.

Bile acids, including DCA, are known to be anionic detergents. These agents in large amounts, usually $>5 \mathrm{mM}$, cause destruction of the parenchyma of pancreas and subsequent release of the constituents of the secretory granules $(22,23)$. Also, large amounts of DCA by itself stimulate the hydrolysis of phosphoinositides by the action of phospholipase $\mathrm{C}$ in an agonistindependent manner in horse platelets (24). During the studies on the causal relationship between bile acids and biliary pancreatitis, we have found a new action of DCA that is different from those observed previously (22-24); that is, small amounts $(0.1-0.5 \mathrm{mM})$ of this bile acid sensitize the pancreatic acini and enhance the secretagogue-induced DG formation, and thereby potentiate secretion. DCA by itself in these amounts does not induce DG formation or secretion. In this paper, this new action 
of DCA in the secretory mechanism in isolated pancreatic acini is described. Possible relationship between this action of DCA and biliary pancreatitis is also discussed.

\section{Methods}

Materials and chemicals. Soybean trypsin inhibitor, carbachol, and all phospholipid standards were purchased from Sigma Chemical Co., St. Louis, MO. $\mathrm{CCK}_{8}$ (sulfate form) was from Peptide Institute Inc., Osaka, Japan. $\left[{ }^{3} \mathrm{H}\right]$ Arachidonic acid $(100 \mathrm{Ci} / \mathrm{mmol})$, $\left[{ }^{32} \mathrm{P}\right]$ orthophosphoric acid (carrier free), myo- $\left[2-{ }^{3} \mathrm{H}\right]$ inositol $(14.2 \mathrm{Ci} / \mathrm{mmol}), \mathrm{N}$ $\left[{ }^{3} \mathrm{H}\right]$ methylscopolamine $(70 \mathrm{Ci} / \mathrm{mmol})$, and $\left[{ }^{125} \mathrm{I}\right] \mathrm{CCK}_{8}$ (labeled with Bolton and Hunter reagent, 2,000 Ci/mmol) were from Amersham Corp., Arlington Heights, IL. Purified collagenase was from Worthington Biochemical Corp., Freehold, NJ; minimal Eagle's medium amino acid supplement with L-glutamine was from Gibco (Grand Island, NY); quin 2 acetoxymethyl ester was from Dojindo Laboratories (Kumamoto, Japan); bovine serum albumin (fraction V) was from Armour Pharmaceutical Co., Tarrytown, NY; ionomycin was from Calbiochem-Behring Corp., San Diego, CA; and Soluene-100 was from Hewlett-Packard Co., Palo Alto, CA. DCA, cholate, chenodeoxycholate, ursodeoxycholate, and sodium taurocholate were purchased from Difco Laboratories, Detroit, MI, Wako Pure Chemicals, Osaka, Japan, Aldrich Chemical Co., Milwaukee, WI, Sigma Chemical Co., and Calbiochem-Behring Corp., respectively. Dehydrocholate was a generous gift from Dr. K. Uchida (Shionogi Research Laboratories, Osaka, Japan). Triton X-100 was provided by Nakarai Chemicals (Kyoto, Japan). Other materials and chemicals were obtained from commercial sources.

Preparation of pancreatic acini. Isolated pancreatic acini were prepared from starved male Wistar rat $(200-250 \mathrm{~g})$ as described by Williams et al. (25) utilizing the following procedures. The pancreas was removed from the decapitated and exsanguinated rat. Krebs-Henseleit bicarbonate medium ( $\mathrm{pH} 7.4$ ), containing $70 \mathrm{U} / \mathrm{ml}$ of purified collagenase, $0.1 \mathrm{mg} /$ $\mathrm{ml}$ of soybean trypsin inhibitor, $0.25 \%$ bovine serum albumin, $11.1 \mathrm{mM}$ glucose, minimal Eagle's medium amino acid supplement, and $0.1 \mathrm{mM}$ $\mathrm{CaCl}_{2}$ were injected into the interstitium of the pancreas. The pancreas was then incubated in $5 \mathrm{ml}$ of the same medium for $10 \mathrm{~min}$ at $37^{\circ} \mathrm{C}$. After the incubation, excess medium was aspirated and replaced with 5 $\mathrm{ml}$ of a fresh medium, and the incubation was continued for an additional $35 \mathrm{~min}$. The pancreas was mechanically dispersed into acini by forceful pipetting through plastic pipettes and filtered through $150-\mu \mathrm{m}$ mesh nylon cloth. The filtrate was layered over an 8-ml cushion of Krebs-Henseleit bicarbonate medium containing $4 \%$ bovine serum albumin, $0.1 \mathrm{mg} / \mathrm{ml}$ of soybean trypsin inhibitor, and $1.2 \mathrm{mM} \mathrm{CaCl}_{2}$, and then centrifuged at $50 \mathrm{~g}$ for $3 \mathrm{~min}$ to remove blood cells and other tissues. The acini were then washed and resuspended in an appropriate volume of Hepes-buffered Ringer's solution (Ringer's solution containing $10 \mathrm{mM}$ Hepes at pH 7.4, adequate volume of essential amino acids, $0.5 \%$ bovine serum albumin, and $0.1 \mathrm{mg} / \mathrm{ml}$ of soybean trypsin inhibitor) that was gassed with oxygen before use. All procedures except incubations were performed at room temperature.

Assay for amylase secretion. The acini were resuspended in an appropriate volume of Hepes-buffered Ringer's solution at a density of 2$3 \mathrm{mg} / \mathrm{ml}$ of protein in a $50-\mathrm{ml}$ polycarbonate Erlenmeyer flask and preincubated for $60 \mathrm{~min}$ at $37^{\circ} \mathrm{C}$. After the preincubation, the acini were resuspended in an appropriate volume of the same fresh solution at a density of $\sim 0.5 \mathrm{mg} / \mathrm{ml}$ of protein. $2-\mathrm{ml}$ aliquots were distributed into 25 -ml polycarbonate Erlenmeyer flasks, gassed with oxygen for $20 \mathrm{~s}$, and then incubated for $20 \mathrm{~min}$ at $37^{\circ} \mathrm{C}$ with carbachol or $\mathrm{CCK}_{8}$ in the presence or absence of DCA as indicated in each experiment. After the incubation, $1-\mathrm{ml}$ aliquots were taken and immediately centrifuged at $10,000 \mathrm{~g}$ for $20 \mathrm{~s}$. The amylase activites of the supernatants thus obtained were measured by the method of Irie et al. (26). The amylase secretion was expressed as the ratio of the value of amylase activity secreted into the medium during the incubation to that of the total amylase content. The total amylase content was estimated by measuring the enzymatic activity of $1-\mathrm{ml}$ aliquots of unstimulated acinar suspension after disruption of the acinar cells by sonication.
Assay for DG formation. To measure DG formation, 40-mg proteins of acini were preincubated with $100 \mu \mathrm{Ci}$ of $\left[{ }^{3} \mathrm{H}\right]$ arachidonic acid in 20 $\mathrm{ml}$ of Hepes-buffered Ringer's solution for $60 \mathrm{~min}$ at $37^{\circ} \mathrm{C}$. Then, the radiolabeled acini were washed and resuspended in an appropriate volume of Hepes-buffered Ringer's solution at a density of $0.5 \mathrm{mg} / \mathrm{ml}$ of protein. $1-\mathrm{ml}$ aliquots were distributed into test tubes and incubated for $2 \mathrm{~min}$ at $37^{\circ} \mathrm{C}$ with carbachol or $\mathrm{CCK}_{8}$ in the presence or absence of DCA as indicated in each experiment. The reaction was terminated by the addition of $3.75 \mathrm{ml}$ of chloroform/methanol (1:2) mixture, and radioactive lipids were directly extracted by the method of Bligh and Dyer (27). Phospholipids, DG, and arachidonic acid metabolites were separated by Silica Gel $\mathrm{G}$ plate thin-layer chromatography with a solvent system of benzene/ diethyl ether/ethanol/ammonium water (100:80:4:0.2). The area corresponding to 1,2-DG was scraped into a vial and the radioactivity was determined.

Assay for ${ }^{32} P$-incorporation into PI. To measure ${ }^{32} \mathrm{P}$-incorporation into PI, 40-mg proteins of acini were suspended in $15 \mathrm{ml}$ of Hepesbuffered Ringer's solution with $60 \mu \mathrm{Ci}$ of [ $\left.{ }^{32} \mathrm{P}\right] \mathrm{Pi}$ and incubated for 30 min at $37^{\circ} \mathrm{C}$ as described by Halenda and Rubin (28). The radiolabeled acini were washed and resuspended in an appropriate volume of Hepesbuffered Ringer's solution at a density of $1.0 \mathrm{mg} / \mathrm{ml}$ of protein. $1-\mathrm{ml}$ aliquots were distributed into test tubes and incubated for $10 \mathrm{~min}$ at $37^{\circ} \mathrm{C}$ with carbachol or $\mathrm{CCK}_{8}$ in the presence or absence of DCA as indicated in each experiment. The reaction was terminated by the addition of $3.75 \mathrm{ml}$ of chloroform/methanol (1:2) mixture, and radioactive lipids were directly extracted as described above. Phospholipids were separated by Silica Gel G plate thin-layer chromatography with a solvent system of methylacetate/ $n$-propanol/chloroform/methanol/ $0.21 \%$ aqueous $\mathrm{KCl}$ (25:25:25:10:9). The area corresponding to PI was scraped into a vial and the radioactivity was determined.

Measurement of $\left[\mathrm{Ca}^{2+}\right] \mathrm{i}$. $\left[\mathrm{Ca}^{2+}\right] \mathrm{i}$ in isolated acini were measured by the method utilizing the $\mathrm{Ca}^{2+}$ selective fluorescent indicator quin 2 as described by Tsien et al. (29). The acini were suspended in $20 \mathrm{ml}$ of Krebs-Henseleit bicarbonate medium containing $0.5 \mathrm{mM} \mathrm{CaCl}_{2}, 50 \mu \mathrm{M}$ EGTA, and $20 \mathrm{mM}$ Hepes (pH 7.4) at a density of $1 \mathrm{mg} / \mathrm{ml}$ of protein, and incubated for $15 \mathrm{~min}$ at $37^{\circ} \mathrm{C}$. After washing by centrifugation at $50 \mathrm{~g}$ for $3 \mathrm{~min}$, the acini were resuspended in $20 \mathrm{ml}$ of the same buffer containing $100 \mu \mathrm{M}$ quin 2 acetoxymethyl ester, and incubated for 15 $\min$ at $37^{\circ} \mathrm{C}$. The acini were then centrifuged at $50 \mathrm{~g}$ for $3 \mathrm{~min}$ and resuspended at a density of $1 \mathrm{mg} / \mathrm{ml}$ of protein in fresh Krebs-Henseleit bicarbonate medium containing $1.0 \mathrm{mM} \mathrm{CaCl}_{2}$, and kept at room temperature. To measure quin 2 fluorescence, $1 \mathrm{ml}$ of this stock suspension was transferred to the cuvette, and its fluorescence was recorded at $37^{\circ} \mathrm{C}$ in an Hitachi fluorescence spectrophotometer, model 650-60. Excitation and emission wavelengths were set at 339 and $492 \mathrm{~nm}$, respectively.

Assay for the generation of phosphorylated inositols. Phosphoinositides in the acini were prelabeled by the addition of $100 \mu \mathrm{Ci} / \mathrm{ml}$ of myo- $[2$ ${ }^{3} \mathrm{H}$ ]inositol during the last 35 -min period of collagenase digestion utilizing the method of Streb et al. (20). The radiolabeled acini were washed twice with Hepes-buffered Ringer's solution and suspended in an appropriate volume of the same solution at a density of $1 \mathrm{mg} / \mathrm{ml}$ of protein. $1-\mathrm{ml}$ aliquots of the acini were distributed into test tubes and incubated with carbachol or $\mathrm{CCK}_{8}$ in the presence of $5 \mathrm{mM} \mathrm{LiCl}$ for various periods of time as indicated in each experiment. DCA $(0.25 \mathrm{mM})$ was added where indicated. The reaction was terminated by the addition of chloroform/ methanol/HCl (1:2:0.02) mixture. After the addition of $1 \mathrm{ml}$ of chloroform and $1 \mathrm{ml}$ of distilled water, 3-ml aliquots were collected from methanol layer and $5 \mathrm{ml}$ of distilled water was added. After the sample was neutralized with $1 \mathrm{~N} \mathrm{NaOH}$, phosphorylated inositols were separated on Dowex anion exchange columns as described by Berridge (30). The radioactivity of each separated phosphorylated inositol fraction was determined.

Assay for $\mathrm{N}-\left[{ }^{3} \mathrm{H}\right]$ methylscopolamine- and ${ }^{125}$ I-labeled $C C K_{8}$-binding to pancreatic acini. The binding assay for muscarinic cholinergic receptors on pancreatic acini was performed using $N-\left[{ }^{3} \mathrm{H}\right]$ methylscopolamine by the method of Dehaye et al. (31). The acini were suspended in an appropriate volume of Hepes-buffered Ringer's solution at a density of 0.5 $\mathrm{mg} / \mathrm{ml}$ of protein. 1-ml aliquots were distributed into test tubes and 
incubated for $60 \mathrm{~min}$ at $37^{\circ} \mathrm{C}$ with various doses of $N-\left[{ }^{3} \mathrm{H}\right]-$ methylscopolamine in the presence or absence of DCA $(0.25 \mathrm{mM})$. At the end of the incubation period, the aliquots were centrifuged at $300 \mathrm{~g}$ for $2 \mathrm{~min}$ at $4^{\circ} \mathrm{C}$. The pellets were obtained, and then washed twice with $0.9 \%$ saline at $4^{\circ} \mathrm{C}$. The washed pellets were dissolved into $0.5 \mathrm{ml}$ of Soluene-100 and their radioactivities were determined.

The binding assay for $\mathrm{CCK}_{8}$ receptors on pancreatic acini was performed using [ $\left.{ }^{125} \mathrm{I}\right] \mathrm{CCK}_{8}$ as a tracer by the method of Miller et al. (32) with a slight modification. The acini were suspended in an appropriate volume of Hepes-buffered Ringer's solution at a density of $0.5 \mathrm{mg} / \mathrm{ml}$ of protein. 1-ml aliquots were distributed into test tubes and incubated for $60 \mathrm{~min}$ at $37^{\circ} \mathrm{C}$ with various doses of $\left[{ }^{125} \mathrm{I}\right] \mathrm{CCK}_{8}$ in the presence or absence of DCA $(0.25 \mathrm{mM})$. At the end of incubation period, the aliquots were centrifuged at $300 \mathrm{~g}$ for $2 \mathrm{~min}$ at $4^{\circ} \mathrm{C}$. The pellets were obtained, and then washed twice with $0.9 \%$ saline at $4^{\circ} \mathrm{C}$. The washed pellets were dissolved with $0.5 \mathrm{ml}$ of $0.5 \mathrm{~N} \mathrm{NaOH}$ and their radioactivities were determined.

Determinations. Protein was determined by the method of Lowry et al. (33) with bovine serum albumin as a standard protein. Radioactivity of ${ }^{3} \mathrm{H}$ - and ${ }^{32} \mathrm{P}$-labeled samples was determined using a Packard Tri-Carb liquid scintillation spectrometer, Model 3330 , and that of ${ }^{125}$ I-labeled samples was determined using an Aloka auto well gamma system ARC-251.

\section{Results}

\section{Enhancement of secretagogue-induced amylase secretion by DCA}

Incubation of isolated pancreatic acini with various doses of carbachol or $\mathrm{CCK}_{8}$ caused marked amylase secretion in a dosedependent manner as shown in Fig. 1. The maximal and halfmaximal effects were observed with $3 \times 10^{-6} \mathrm{M}$ and $3 \times 10^{-7}$ $\mathrm{M}$ for carbachol and $1 \times 10^{-10} \mathrm{M}$ and $3 \times 10^{-11} \mathrm{M}$ for $\mathrm{CCK}_{8}$, respectively. These results are consistent with those reported previously by other investigators $(25,34)$. When $0.25 \mathrm{mM}$ DCA was added to the acini during the incubation with each secretagogue, the dose-response curves for each secretagogue were moved left and DCA markedly enhanced amylase secretion, which had been induced by submaximal doses of the secretagogue. DCA enhanced the maximal levels of this reaction only

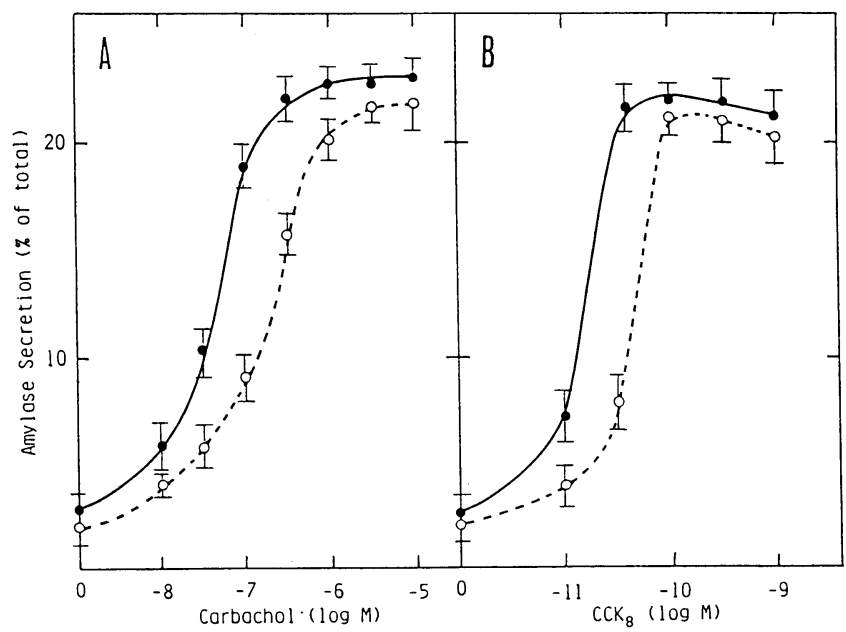

Figure 1. Enhancement by DCA of amylase secretion induced by carbachol or $\mathrm{CCK}_{8}$. The acini were incubated for $20 \mathrm{~min}$ at $37^{\circ} \mathrm{C}$ with various doses of either carbachol or $\mathbf{C C K}_{8}$ in the presence or absence of $0.25 \mathrm{mM}$ DCA, and amylase secretion was assayed as described in Methods. (A) With carbachol. (B) With $\mathrm{CCK}_{8}$. (Open circles) In the absence of DCA. (Solid circles) In the presence of DCA. Results are the means $\pm \mathrm{SE}$ of three independent experiments.

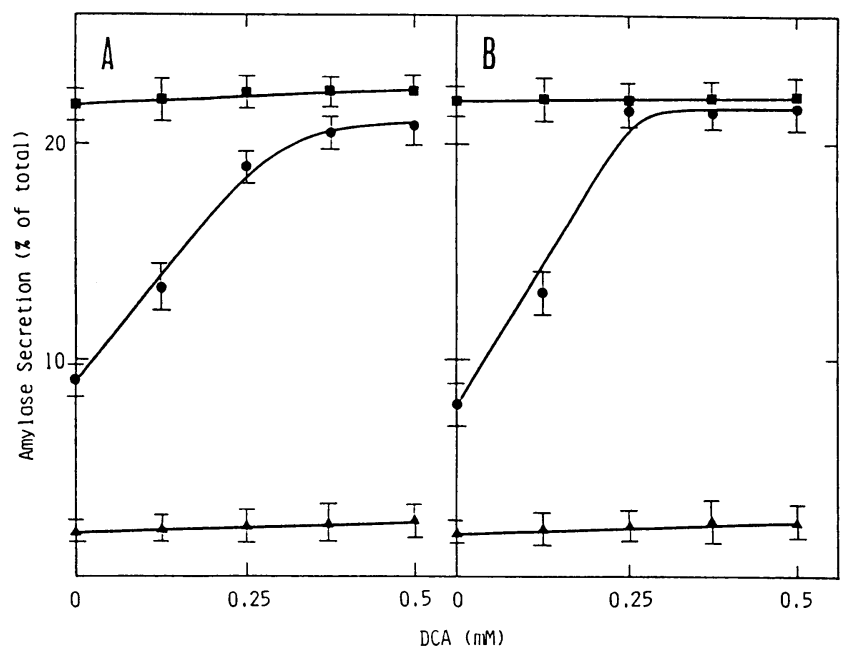

Figure 2. Dose effect of DCA on amylase secretion induced by carbachol or $\mathrm{CCK}_{8}$. The acini were incubated for $20 \mathrm{~min}$ at $37^{\circ} \mathrm{C}$ with indicated doses of either carbachol or $\mathrm{CCK}_{8}$ in the presence of various amounts of DCA, and amylase secretion was assayed as described in Methods. (A) With carbachol. (B) With $\mathrm{CCK}_{8}$. (Triangles) Without secretagogue. (Circles) With $1 \times 10^{-7} \mathrm{M}$ carbachol or with $3 \times 10^{-11} \mathrm{M}$ $\mathrm{CCK}_{8}$. (Squares) With $3 \times 10^{-6} \mathrm{M}$ carbachol or with $1 \times 10^{-10} \mathrm{M}$ $\mathrm{CCK}_{8}$. Results are the means $\pm \mathrm{SE}$ of three independent experiments.

slightly. Fig. 2 shows the dose-response curves of DCA on the amylase secretion elicited by submaximal and maximal doses of carbachol or $\mathrm{CCK}_{8}$. Increasing amounts of DCA enhanced progressively amylase secretion, which had been induced by the submaximal dose of each secretagogue, but showed little effect on the maximal levels of this reaction. DCA alone in the amounts used in this experiment did not induce amylase secretion in the absence of the secretagogue. Under these conditions, DCA did not destroy the cells as judged by a trypan blue exclusion test.

\section{Specificity for bile acids}

A stimulatory effect of DCA on the carbachol- or $\mathrm{CCK}_{8}$-induced amylase secretion was observed also with other bile acids such as cholate, chenodeoxycholate, ursodeoxycholate, and taurocholate, as shown in Table I. Dehydrocholate was inactive in this capacity. These bile acids by themselves did not induce amylase secretion in the absence of the secretagogue.

Table I. Effects of Various Bile Acids on Amylase Secretion Induced by Carbachol or $\mathrm{CCK}_{8}^{*}$

\begin{tabular}{llrr}
\hline & \multicolumn{3}{l}{ Amylase secretion (\% of total) } \\
\cline { 2 - 4 } Bile acids & $\begin{array}{l}\text { Without } \\
\text { secretagogue }\end{array}$ & $\begin{array}{l}1 \times 10^{-7} \mathrm{M} \\
\text { carbachol }\end{array}$ & \multicolumn{1}{c}{$\begin{array}{l}3 \times 10^{-11} \mathrm{M} \\
\text { CCK }^{\prime}\end{array}$} \\
\hline None & $2.1 \pm 0.5$ & $9.0 \pm 1.0$ & $8.3 \pm 1.2$ \\
DCA & $2.3 \pm 0.5$ & $18.2 \pm 1.3$ & $20.6 \pm 0.8$ \\
Cholate & $2.5 \pm 0.6$ & $17.5 \pm 0.9$ & $18.6 \pm 1.2$ \\
Chenodeoxycholate & $2.4 \pm 0.5$ & $17.7 \pm 1.3$ & $19.2 \pm 1.4$ \\
Ursodeoxycholate & $2.1 \pm 0.6$ & $16.8 \pm 1.5$ & $18.9 \pm 0.9$ \\
Taurocholate & $2.4 \pm 0.4$ & $14.8 \pm 0.8$ & $16.2 \pm 1.5$ \\
Dehydrocholate & $2.0 \pm 0.5$ & $9.2 \pm 1.4$ & $9.0 \pm 0.9$ \\
\hline
\end{tabular}

* The acini were incubated for $20 \mathrm{~min}$ at $37^{\circ} \mathrm{C}$ with or without indicated dose of either carbachol or $\mathrm{CCK}_{8}$ in the presence or absence of $0.25 \mathrm{mM}$ each bile acid, and amylase secretion was assayed as described in Methods. Results are the means \pm SE of three independent experiments. 


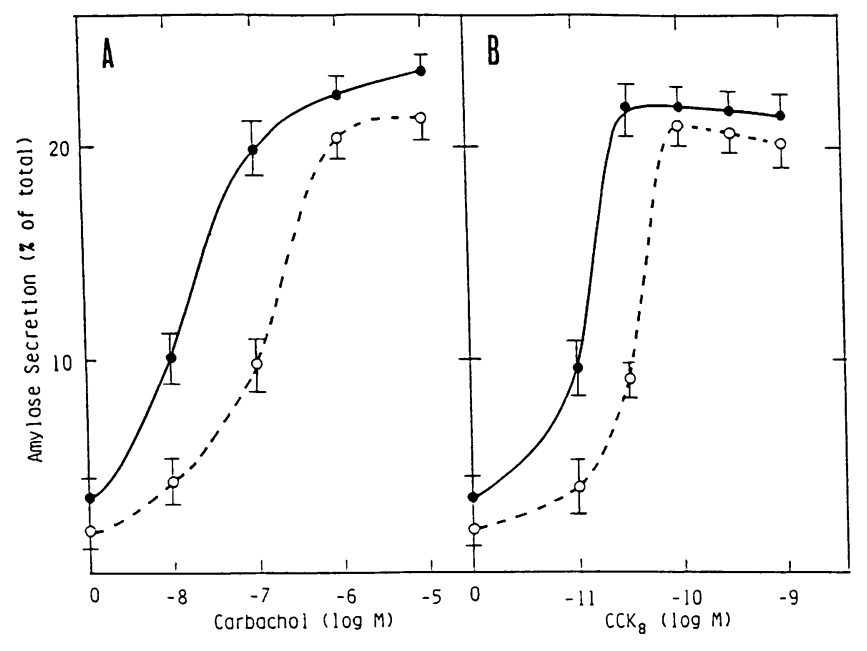

Figure 3. Enhancement by Triton X-100 of amylase secretion induced by carbachol or $\mathrm{CCK}_{8}$. The acini were incubated for $20 \mathrm{~min}$ at $37^{\circ} \mathrm{C}$ with various doses of either carbachol or $\mathrm{CCK}_{8}$ in the presence or absence of $0.001 \%$ Triton X-100, and amylase secretion was assayed as described in Methods. $(A)$ With carbachol. $(B)$ With $\mathrm{CCK}_{8}$. (Open circles) In the absence of Triton X-100. (Solid circles) In the presence of Triton X-100. Results are the means \pm SE of three independent experiments.

A small amount $(0.001 \%)$ of Triton X-100 also showed a similar stimulatory effect on the carbachol- or $\mathrm{CCK}_{\mathbf{8}}$-induced amylase secretion as shown in Fig. 3. Triton X-100 in the range of 0.0002 to $0.001 \%$ was effective in this capacity in a dosedependent manner. Triton X-100 alone in the amounts used in this experiment did not induce amylase secretion. Under these conditions, Triton X-100 did not destroy the cells as judged by a trypan blue exclusion test. However, Triton X-100 alone in the amounts $>0.1 \%$ destroyed the cells and caused full amylase secretion even in the absence of the secretagogue.

\section{Ineffectiveness of DCA on amylase secretion induced} by TPA plus $\mathrm{Ca}^{2+}$ ionophore

Consistent with the recent observations made by de Pont and Fleuren-Jacobs (16), incubation of the acini with various doses of TPA resulted in the induction of amylase secretion in a dosedependent manner as shown in Fig. 4. This reaction, which was

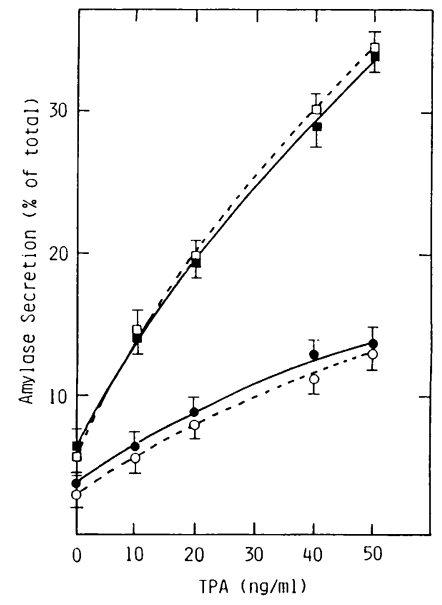

Figure 4. Ineffectiveness of DCA on amylase secretion induced by TPA plus $\mathrm{Ca}^{2+}$ ionophore. The acini were incubated for $20 \mathrm{~min}$ at $37^{\circ} \mathrm{C}$ with the combination of various doses of TPA and $2 \mu \mathrm{M}$ ionomycin in the presence or absence of $0.25 \mathrm{mM} \mathrm{DCA}$, and amylase secretion was assayed as described in Methods. (Open and solid circles) Without ionomycin. (Open and solid squares) With ionomycin. (Open circles and open squares) In the absence of DCA. (Solid circles and solid squares) In the presence of DCA. Results are the means \pm SE of three independent experiments.

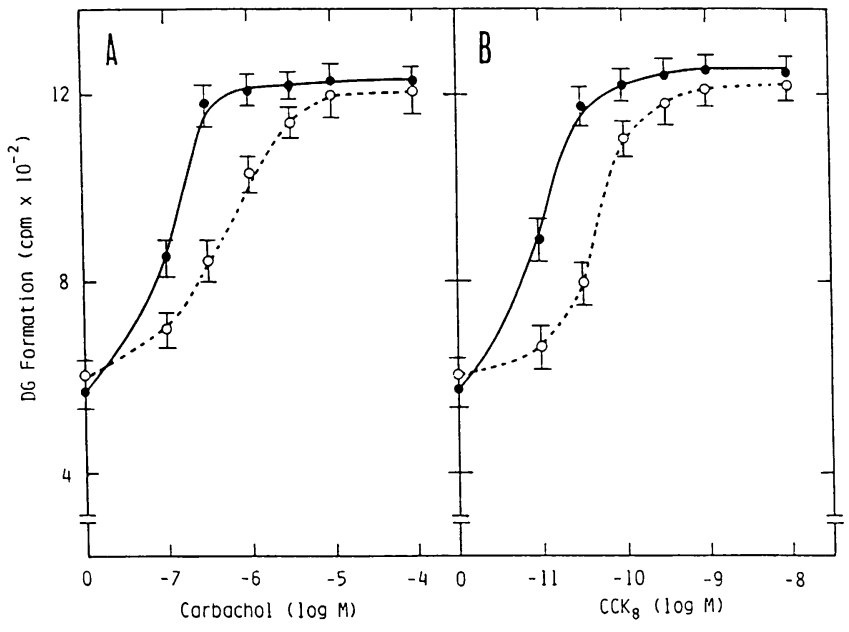

Figure 5. Enhancement by DCA of DG formation induced by carbachol or $\mathrm{CCK}_{8}$. The acini labeled with $\left[{ }^{3} \mathrm{H}\right]$ arachidonic acid were incubated for $2 \mathrm{~min}$ at $37^{\circ} \mathrm{C}$ with various doses of either carbachol or $\mathrm{CCK}_{8}$ in the presence or absence of $0.25 \mathrm{mM}$ DCA. Detailed procedures are described in Methods. $(A)$ With carbachol. $(B)$ With $\mathrm{CCK}_{8}$. (Open circles) In the absence of DCA. (Closed circles) In the presence of DCA. Results are the means \pm SE of three independent experiments.

induced by TPA, was synergistically enhanced by the simultaneous addition of $\mathrm{Ca}^{2+}$ ionophore ionomycin, which by itself induced amylase secretion slightly. DCA did not affect amylase secretion that was elicited in this way, in marked contrast to the action of this agent in the secretion induced by the natural secretagogue.

\section{Enhancement of secretagogue-induced DG formation and phosphoinositide turnover by $D C A$}

Incubation of the acini with various doses of carbachol or $\mathrm{CCK}_{8}$ caused rapid DG formation and subsequent phosphoinositide turnover as shown in Figs. 5 and 6, respectively. The doses of each secretagogue necessary for DG formation and phosphoino-

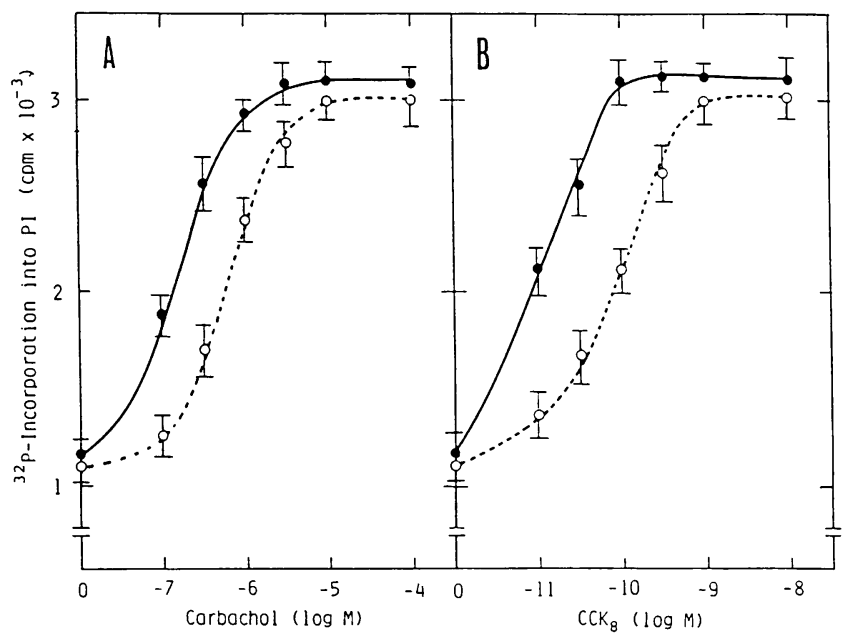

Figure 6. Enhancement by DCA of ${ }^{32} \mathrm{P}$-incorporation into PI induced by carbachol or $\mathrm{CCK}_{8}$. The acini labeled with $\left.{ }^{32} \mathrm{P}\right] \mathrm{Pi}$ were incubated for $10 \mathrm{~min}$ at $37^{\circ} \mathrm{C}$ with various doses of either carbachol or $\mathrm{CCK}_{8}$ in the presence or absence of $0.25 \mathrm{mM}$ DCA. Detailed procedures are described in Methods. $(A)$ With carbachol. $(B)$ With $\mathrm{CCK}_{8}$. (Open circles) In the absence of DCA. (Closed circles) In the presence of DCA. Results are the means $\pm \mathrm{SE}$ of three independent experiments. 
sitide turnover were nearly the same, but were slightly higher than those necessary for amylase secretion (see also Fig. 1). DCA enhanced both DG formation and phosphoinositide turnover, which had been induced by submaximal doses of each secretagogue, but showed little effect on the maximal levels of these reactions. This effect of DCA was dose dependent in the range between 0.1 and $0.5 \mathrm{mM}$, and the doses of this compound necessary for the enhancement of DG formation and phosphoinositide turnover were nearly the same as those necessary for the enhancement of amylase secretion (see also Fig. 2). DCA alone did not elicit DG formation or phosphoinositide turnover in the amounts used in these experiments.

\section{Ineffectiveness of DCA on secretagogue-induced $\mathrm{Ca}^{2+}$ mobilization}

Carbachol raised $\left[\mathrm{Ca}^{2+}\right] \mathrm{i}$ in a dose-dependent manner as shown in Fig. 7. The significant elevation of $\left[\mathrm{Ca}^{2+}\right] \mathrm{i}$ was obtained by 1 $\times 10^{-6} \mathrm{M}$ carbachol and the maximal elevation was obtained by $1 \times 10^{-5} \mathrm{M}$. The doses of the secretagogue necessary for $\mathrm{Ca}^{2+}$ mobilization were nearly the same as those necessary for DG formation and phosphoinositide turnover, but slightly higher than those necessary for amylase secretion (see also Figs. 1, 5, and 6). These results are consistent with the earlier observations (35). However, in contrast to the effects of DCA on the secretagogue-induced DG formation and phosphoinositide turnover, this compound ( $0.25 \mathrm{mM}$ ) showed no significant effect on $\mathrm{Ca}^{2+}$ mobilization induced by any doses of carbachol as shown in Fig. 7. DCA alone did not affect $\left[\mathrm{Ca}^{2+}\right] \mathrm{i}$ in the absence of the secretagogue.

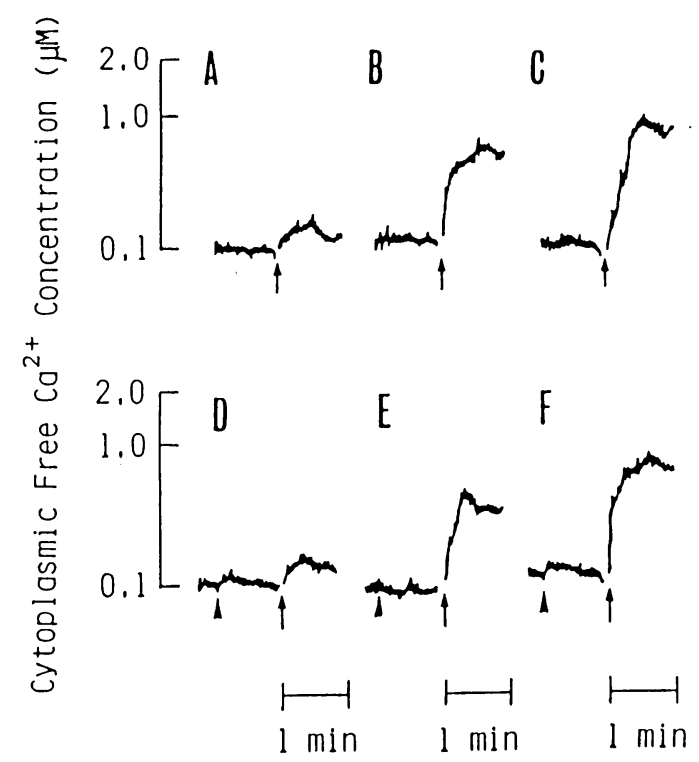

Figure 7. Ineffectiveness of DCA on carbachol-induced increase of $\left[\mathrm{Ca}^{2+}\right]$ i. The acini loaded with quin 2 were stimulated with various doses of carbachol in the presence or absence of $0.25 \mathrm{mM}$ DCA. Detailed procedures are described in Methods. $(A)$ With $1 \times 10^{-6} \mathrm{M}$ carbachol. (B) With $5 \times 10^{-6} \mathrm{M}$ carbachol. (C) With $1 \times 10^{-5} \mathrm{M}$ carbachol. $(D)$ With $1 \times 10^{-6} \mathrm{M}$ carbachol in the presence of DCA. $(E)$ With $5 \times 10^{-6} \mathrm{M}$ carbachol in the presence of DCA. $(F)$ With 1 $\times 10^{-5} \mathrm{M}$ carbachol in the presence of DCA. $A$ and $\uparrow$ indicate the points of the addition of DCA and carbachol, respectively. The data shown are typical of three independent experiments using acini from different rats.
The essentially similar results were obtained when the cells were stimulated by $\mathrm{CCK}_{8}$ instead of carbachol. Namely, $\mathrm{CCK}_{8}$ also raised $\left[\mathrm{Ca}^{2+}\right] \mathrm{i}$ in a dose-dependent manner. The doses of $\mathrm{CCK}_{8}$ necessary for $\mathrm{Ca}^{2+}$ mobilization were nearly the same as those necessary for DG formation and phosphoinositide turnover, but were slightly higher than those necessary for amylase secretion. DCA had no significant effect on $\left[\mathrm{Ca}^{2+}\right]$ i when elevated by varying doses of $\mathrm{CCK}_{8}$.

\section{Differential action of $D C A$ in the generation of phosphorylated inositols}

When the acini were incubated with various doses of carbachol, inositol-monophosphate (IP), inositol-bisphosphate $\left(\mathrm{IP}_{2}\right)$, and $\mathrm{IP}_{3}$ were accumulated in a dose-dependent manner as shown in Fig. 8. The doses of carbachol necessary for the generation of these phosphorylated inositols were nearly the same as those necessary for DG formation, phosphoinositide turnover, and $\mathrm{Ca}^{2+}$ mobilization, but were slightly higher than those necessary for amylase secretion (see also Figs. 1, 5-7). Fig. 9 shows the time courses for the carbachol-induced generation of IP, $\mathrm{IP}_{2}$, and $\mathrm{IP}_{3}$. Among the three phosphorylated inositols, $\mathrm{IP}_{3}$ was most rapidly produced, followed by the production of $\mathrm{IP}_{2}$ and IP.

The addition of DCA to the acini during the incubation with carbachol caused marked enhancement of the generation of IP and $\mathrm{IP}_{2}$ induced by submaximal doses of the secretagogue as demonstrated in Figs. 8 and 9. DCA showed little effect on the maximal levels of these reactions. However, DCA did not show a significant effect on the generation of $\mathrm{IP}_{3}$ induced by submaximal and maximal doses of carbachol. DCA alone did not stimulate the generation of $\mathrm{IP}, \mathrm{IP}_{2}$, and $\mathrm{IP}_{3}$ in the amount used in these experiments.

The essentially similar results were obtained when the cells were stimulated by $\mathrm{CCK}_{8}$ instead of carbachol. Namely, $\mathrm{CCK}_{8}$ also stimulated the accumulation of the three species of phosphorylated inositols in dose- and time-dependent manners. The doses of $\mathrm{CCK}_{8}$ necessary for these reactions were nearly the same

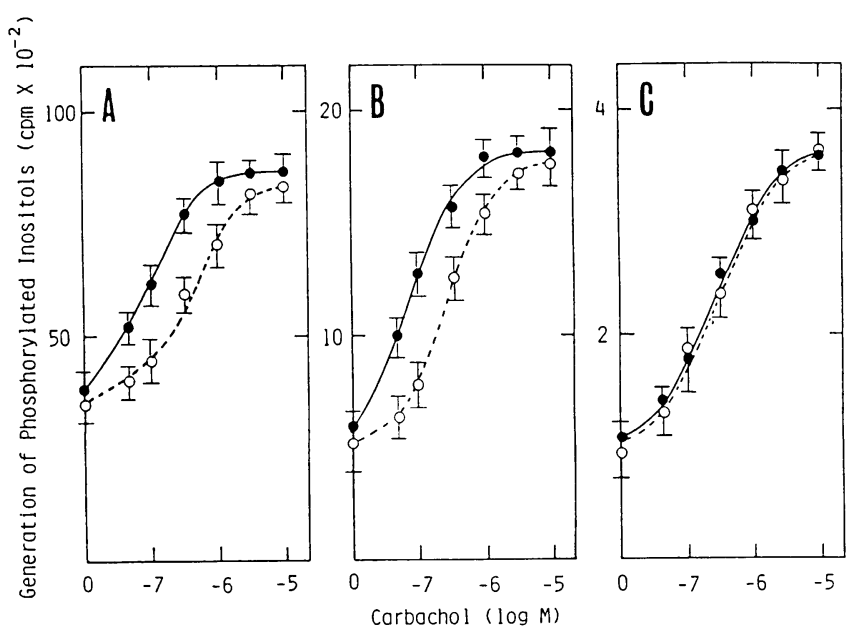

Figure 8. Effect of DCA on carbachol-induced generation of phosphorylated inositols. The acini labeled with myo- $\left[2-{ }^{3} \mathrm{H}\right]$ inositol were incubated for $1.5 \mathrm{~min}$ at $37^{\circ} \mathrm{C}$ with various doses of carbachol in the presence or absence of $0.25 \mathrm{mM}$ DCA. Detailed procedures are described in Methods. $(A) \mathrm{IP} ;(B) \mathrm{IP}_{2}$; and $(C) \mathrm{IP}_{3}$. (Open circles) In the absence of DCA. (Solid circles) In the presence of DCA. Results are the means $\pm \mathrm{SE}$ of three independent experiments. 


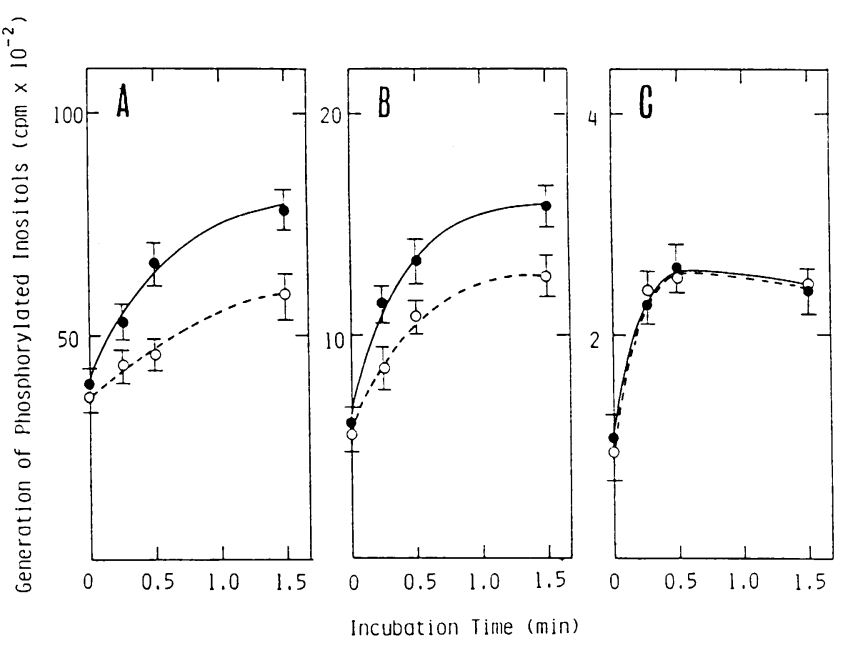

Figure 9. Time courses of carbachol-induced generation of phosphorylated inositols in the presence or absence of DCA. The acini labeled with myo- $\left[2-{ }^{3} \mathrm{H}\right]$ inositol were incubated at $37^{\circ} \mathrm{C}$ with $3 \times 10^{-7} \mathrm{M}$ carbachol in the presence or absence of $0.25 \mathrm{mM}$ DCA for various periods of time. Detailed procedures are described in Methods. $(A)$ IP; $(B)$ $\mathrm{IP}_{2}$; and $(C) \mathrm{IP}_{3}$. (Open circles) In the absence of DCA. (Solid circles) In the presence of DCA. Results are the means $\pm S E$ of three independent experiments.

as those necessary for DG formation, phosphoinositide turnover, and $\mathrm{Ca}^{2+}$ mobilization, but were slightly higher than those necessary for amylase secretion. DCA showed a stimulatory effect on the $\mathrm{CCK}_{8}$-induced formation of IP and $\mathrm{IP}_{2}$ but did not affect the $\mathrm{CCK}_{8}$-induced formation of $\mathrm{IP}_{3}$.

Rubin (36) has shown that the doses of caerulein necessary for the generation of the three phosphorylated inositols are over tenfold higher than those necessary for amylase secretion in rat pancreatic acini. Powers et al. (37) have also shown that the doses of carbachol necessary for the former reactions are $\sim 100$ fold higher than those necessary for the latter reaction in mouse pancreatic acini. In our experiments, the doses of carbachol or $\mathrm{CCK}_{8}$ necessary for the generation of the phosphorylated inositols were slightly higher than those necessary for amylase secretion as described above. In this point, our results were inconsistent with these earlier observations $(36,37)$. The exact reason for this difference is unknown, but it is conceivable that this difference may be partly due to the different experimental conditions: we used rat pancreatic acini and carbachol or $\mathrm{CCK}_{8}$ as a secretagogue, whereas Rubin (36) used rat pancreatic acini and caerulein as a secretagogue and Powers et al. (37) used mouse pancreatic acini and carbachol as a secretagogue.

\section{Ineffectiveness of DCA on $\mathrm{N}-\left[{ }^{3} \mathrm{H}\right]$ methylscopolamine- and ${ }^{125}$ I-labeled $\mathrm{CCK}_{8}$-binding to acini}

In the last set of experiments, the effect of DCA on the binding of carbachol or $\mathrm{CCK}_{8}$ to their specific receptors was examined. The binding of carbachol to the muscarinic receptors and that of $\mathrm{CCK}_{8}$ to its specific receptors on isolated pancreatic acini were measured using $N-\left[{ }^{3} \mathrm{H}\right]$ methylscopolamine, an antagonist for the muscarinic cholinergic receptors, and ${ }^{125} \mathrm{I}$-labeled $\mathrm{CCK}_{8}$, respectively, under the conditions specified previously $(31,32)$. These radiolabeled ligands bound to the acini in a dose-dependent manner. The dose of $N-\left[{ }^{3} \mathrm{H}\right]$ methylscopolamine giving the half-maximal binding activity and the maximal binding capacity were $\sim 2 \times 10^{-9} \mathrm{M}$ and $0.16 \mathrm{pmol} / \mathrm{mg}$ protein, respectively. The dose of ${ }^{125}$ I-labeled $\mathrm{CCK}_{8}$ giving the half maximal binding activity and the maximal binding capacity were $\sim 5.0 \times 10^{-11} \mathrm{M}$ and $15 \mathrm{fmol} / \mathrm{mg}$ protein, respectively. The addition of DCA $(0.25$ $\mathrm{mM}$ ) to the acini during the incubation with each ligand did not change these values significantly.

\section{Discussion}

This paper demonstrates that small amounts $(0.1-0.5 \mathrm{mM})$ of DCA sensitize the pancreatic acini and increase the sensitivity to the secretagogues, such as carbachol and $\mathrm{CCK}_{8}$, of DG formation and amylase secretion but not of $\mathrm{IP}_{3}$ formation or $\mathrm{Ca}^{2+}$ mobilization. Evidence is also presented that DCA does not affect the binding of the carbachol antagonist or $\mathrm{CCK}_{8}$ to the acini, and does not affect the amylase secretion induced by TPA plus $\mathrm{Ca}^{2+}$ ionophore. Since it has been described that DG and $\mathrm{Ca}^{2+}$ may be responsible for the secretagogue-induced amylase secretion through the activation of protein kinase $\mathrm{C}$ and $\mathrm{Ca}^{2+}$ receptors, respectively, in isolated pancreatic acini (16-21), these results indicate that DCA may enhance DG formation and subsequent activation of protein kinase $\mathrm{C}$, and thereby potentiate amylase secretion, and that DCA does not modulate the secretory processes subsequent to protein kinase $\mathrm{C}$ and $\mathrm{Ca}^{2+}$ receptors.

It is well established that DG is produced from the hydrolysis of PIP, PIP, and PI by the action of phospholipase C in many cell types, including exocrine pancreas (for reviews, see references 9 and 38). $\mathrm{IP}_{3}, \mathrm{IP}_{2}, \mathrm{IP}$ are generated with $\mathrm{DG}$ from this reaction. In our experiments, DCA enhances the secretagogue-induced generation of $\mathrm{IP}_{2}$ and IP, but does not show a significant effect on the secretagogue-induced generation of $\mathrm{IP}_{3}$. This result is consistent with another observation that DCA does not affect the secretagogue-induced $\mathrm{Ca}^{2+}$ mobilization, since $\mathrm{IP}_{3}$ has been shown to serve as a trigger for intracellular $\mathrm{Ca}^{2+}$ mobilization (9). These results suggest that DCA may potentiate selectively the secretagogue-induced hydrolysis of PIP and PI. However, the possibility can not be completely neglected that DCA stimulates the secretagogue-induced hydrolysis of $\mathrm{PIP}_{2}$, since the stimulatory effect of DCA on the generation of $\mathrm{IP}_{3}$ may be obscured by its rapid breakdown to $\mathrm{IP}_{2}$ and IP.

The stimulatory action of DCA in the secretagogue-induced DG formation and amylase secretion is totally different from that previously observed with large amounts of bile acids (22, 23). Large amounts of DCA, usually more than several millimolars, by themselves are able to induce enzyme release in the absence of the secretagogues. However, in this case, DCA destroys the cells by its potent detergent action, and thereby induces secretion irrespective of the presence or absence of the secretagogues. The novel action of DCA described in this paper is completely dependent on the presence of the secretagogues. The stimulatory effect of DCA on the secretagogue-induced amylase secretion was also observed with other bile acids such as cholate, chenodeoxycholate, ursodeoxycholate, and taurocholate, which are all known to be potent detergents. Dehydrocholate, which is less potent than these bile acids in the detergent action, is ineffective to potentiate amylase secretion. Moreover, a small amount of Triton X-100, a nonionic detergent, also shows the similar effect to that observed with DCA. Triton X-100 has been described to elicit experimental acute pancreatitis (39). Therefore, these results suggest that DCA as well as other active bile acids may exert their stimulatory effects on DG formation as detergents. Nevertheless, DCA in the amounts used in our experiments did not destroy the cells as judged by a trypan blue ex- 
clusion test as well as by the fact that DCA by itself does not increase $\left[\mathrm{Ca}^{2+}\right]$ i. Moreover, the novel action of DCA is not nonspecific, since this compound does not affect amylase secretion induced by TPA plus $\mathrm{Ca}^{2+}$ ionophore, and shows the differential action in the generation of the phosphorylated inositols.

It has been generally accepted that acute pancreatitis is parenchymal damage of pancreatic tissue that is caused by the action of pancreatic digestive enzymes. Many digestive enzymes such as trypsin, chymotrypsin, elastase, amylase, lipase, and phospholipase $\mathrm{A}$ are packed in the form of their proenzymes in the same zymogen granules and secreted together upon stimulation of the cells by secretagogues. Many investigators have postulated that, in biliary pancreatitis, large amounts of bile acids refluxed into the pancreatic duct system liberate the digestive enzymes through the destruction of acinar cells, owing to the detergent action, and the digestive enzymes hypersecreted in this way then play crucial roles in the original parenchymal damage $(2-6,22,23)$. In this action of bile acids, secretion of the digestive enzymes is induced in a manner independent of the secretagogues. In this paper we have presented a novel action of DCA as an enhancer in the secretagogue-induced secretion of the digestive enzymes. In this case, small amounts of bile acids are able to induce hypersecretion of the digestive enzymes only in the presence of the secretagogues. It has been described that retrograde infusions of ferritin or India ink into the pancreatic duct reveals accumulation of these materials in the periacinar space during ductal hypertension $(3,5)$, which indicates that bile acids can be in contact with the basolateral surface of the acinar cells, where they enhance the secretagogue-induced DG formation and protein kinase $\mathrm{C}$ activation. It is conceivable, therefore, that the novel action of bile acids described in this paper may also contribute to the generation of biliary pancreatitis, particularly in the very early stage of this disease. A possible participation of this secretagogue-dependent action of bile acids in the generation of biliary pancreatitis is now under investigation in our laboratories.

\section{Acknowledgments}

The authors are grateful to Miss J. Yamaguchi for her skillful secretarial assistance.

This investigation has been supported in part by research grants from the Scientific Research Fund of the Ministry of Education, Science and Culture, Japan (1984-1986), the Yamanouchi Foundation for Research on Metabolic Disorders (1984, 1985), Japan, and the Research Foundation for Cancer and Cardiovascular Diseases (1985), Japan.

\section{References}

1. Hansson, K. 1967. Experimental and clinical studies in aetiologic role of bile reflux in acute pancreatitis. Acta Chir. Scand. 375(Suppl.): $1-102$.

2. Elliott, D. W., R. D. Williams, and R. M. Zollinger. 1957. Alterations in the resistance to bile in the pathogenesis of acute pancreatitis. Ann. Surg. 146:669-682.

3. Anderson, M. C., and W. R. Schiller. 1968. Microcirculatory dynamics in the normal and inflamed pancreas. Am. J. Surg. 115:118127.

4. Sum, P. T., S. A. Bencosme, and I. T. Beck. 1970. Pathogenesis of bile-induced acute pancreatitis in the dog: experiments with detergents. Am. J. Dig. Dis. 15:637-646.

5. Bockman, D. E., W. R. Schiller, and M. C. Anderson. 1971. Route of retrograde flow in the exocrine pancreas during ductal hypertension. Arch. Surg. 103:321-329.

6. Watanabe, O., F. M. Baccino, M. L. Steer, and J. Meldolesi. 1984. Supramaximal caerulein stimulation and ultrastructure of rat pancreatic acinar cell: early morphological changes during development of experimental pancreatitis. Am. J. Physiol. 246:G457-G467.

7. Schulz, I., and H. H. Stolze. 1980. The exocrine pancreas: the role of secretagogues, cyclic nucleotides, and calcium in enzyme secretion. Ann. Rev. Physiol. 42:127-156.

8. Takai, Y., U. Kikkawa, K. Kaibuchi, and Y. Nishizuka. 1984. Membrane phospholipid metabolism and signal transduction for protein phosphorylation. Adv. Cyclic Nucleotide Protein Phosphorylation Res. Raven Press, New York. 18:119-158.

9. Berridge, M. J., and R. F. Irvine. 1984. Inositol trisphosphate, a novel second messenger in cellular signal transduction. Nature (Lond.). 312:315-321.

10. Kaibuchi, K., Y. Takai, M. Sawamura, M. Hoshijima, T. Fujikura, and Y. Nishizuka. 1983. Synergistic functions of protein phosphorylation and calcium mobilization in platelet activation. J. Biol. Chem. 258:67016704.

11. Yamanishi, J., Y. Takai, K. Kaibuchi, K. Sano, M. Castagna, and Y. Nishizuka. 1983. Synergistic functions of phorbol ester and calcium in serotonin release from human platelets. Biochem. Biophys. Res. Commun. 112:778-786.

12. Kojima, I., H. Lippes, K. Kojima, and H. Rasmussen. 1983. Aldosterone secretion: effect of phorbol ester and A23187. Biochem. Biophys. Res. Commun. 116:555-562.

13. Zawalich, W., C. Brown, and H. Rasmussen. 1983. Insulin secretion: combined effects of phorbol ester and A23187. Biochem. Biophys. Res. Commun. 117:448-455.

14. Kajikawa, N., K. Kaibuchi, T. Matsubara, U. Kikkawa, Y. Takai, and Y. Nishizuka. 1983. A possible role of protein kinase $C$ in signalinduced lysosomal enzyme release. Biochem. Biophys. Res. Commun. 116:743-750.

15. Katakami, Y., K. Kaibuchi, M. Sawamura, Y. Takai, and Y. Nishizuka. 1984. Synergistic action of protein kinase $C$ and calcium for histamine release from rat peritoneal mast cells. Biochem. Biophys. Res. Commun. 121:573-578.

16. de Pont, J. J. H. H. M., and A. M. M. Fleuren-Jacobs. 1984. Synergistic effect of A23187 and a phorbol ester on amylase secretion from rabbit pancreatic acini. FEBS (Fed. Eur. Biochem. Soc.) Lett. 170: 64-68.

17. Banschbach, M. W., R. L. Geison, and M. Hokin-Neaverson. 1974. Acetylcholine increases the level of diglyceride in mouse pancreas. Biochem. Biophys. Res. Commun. 58:714-718.

18. Calderon, P., J. Furnelle, and J. Christophe. 1979. In vitro metabolism in the rat pancreas. III. Effects of carbamylcholine and pancreozymin on the turnover of phosphatidylinositols, 1,2-diacylglycerols and phosphatidylcholines. Biochim. Biophys. Acta. 574:404-413.

19. Putney, J. W., Jr., G. M. Burgess, S. P. Halenda, J. S. Mckinney, and R. P. Rubin. 1983. Effects of secretagogues on $\left[{ }^{32} \mathrm{P}\right]$ phosphatidylinositol 4,5-bisphosphate metabolism in the exocrine pancreas. Biochem. J. 212:483-488.

20. Streb, H., J. P. Heslop, R. F. Irvine, I. Schulz, and M. J. Berridge. 1985. Relationship between secretagogue-induced $\mathrm{Ca}^{2+}$ release and inositol polyphosphate production in permeabilized pancreatic acinar cells. J. Biol. Chem. 260:7309-7315.

21. Streb, H., R. F. Irvine, M. J. Berridge, and I. Schulz. 1983. Release of $\mathrm{Ca}^{2+}$ from a nonmitochondrial intracellular store in pancreatic acinar cells by inositol-1,4,5-trisphosphate. Nature (Lond.). 306:67-69.

22. Ohlsson, K., and A. Eddeland. 1975. Release of proteolytic enzymes in bile-induced pancreatitis in dogs. Gastroenterology. 69:668675.

23. Korbová, L., J. Kohout, F. Maliŝ, V. Balaŝ, J. Ĉiẑková, J. Marek, and A. Cihák. 1977. Inhibitory effect of various cytostatics and cycloheximide on experimental pancreatitis in rats. Gut. 18:913-918.

24. Billah, M. M., E. G. Lapetina, and P. Cuatrecasas. 1980. Phospholipase $\mathrm{A}_{2}$ and phospholipase $\mathrm{C}$ activities of platelets. J. Biol. Chem. 255:10227-10231.

25. Williams, J. A., M. Korc, and R. L. Dormer. 1978. Action of secretagogues on a new preparation of functionally intact, isolated pancreatic acini. Am. J. Physiol. 235:E517-E524. 
26. Irie, A., M. Hunaki, K. Bando, and K. Kawai. 1974. Activation of $\alpha$-amylase in urine. Clin. Chem. Acta. 51:241-245.

27. Bligh, E. G., and W. J. Dyer. 1959. A rapid method of total lipid extraction and purification. Can. J. Biochem. Physiol. 37:911-917.

28. Halenda, S. P., and R. P. Rubin. 1982. Phospholipid turnover in isolated rat pancreatic acini: consideration of the relative roles of phospholipase $\mathrm{A}_{2}$ and phospholipase C. Biochem. J. 208:713-721.

29. Tsien, R. Y., T. Pozzan, and T. J. Rink. 1982. Calcium homeostasis in intact lymphocytes: cytoplasmic free calcium monitored with a new, intracellularly trapped fluorescent indicator. J. Cell Biol. 94:325334.

30. Berridge, M. J. 1983. Rapid accumulation of inositol-trisphosphate reveals that agonists hydrolyse polyphosphoinositides instead of phosphatidylinositol. Biochem. J. 212:849-858.

31. Dehaye, J.-P., J. Winand, P. Poloczek, and J. Christophe. 1984. Characterization of muscarinic cholinergic receptors on rat pancreatic acini by $N-\left[{ }^{3} \mathrm{H}\right]$ methylscopolamine binding: their relationship with calcium 45 efflux and amylase secretion. J. Biol. Chem. 259:294-300.

32. Miller, L. J., S. A. Rosenzweig, and J. D. Jamieson. 1981. Preparation and characterization of a probe for cholecystokinin octapeptide receptor, $\mathrm{N}^{\alpha}\left({ }^{125} \mathrm{I}\right.$-desaminotyrosyl)CCK-8, and its interactions with pancreatic acini. J. Biol. Chem. 256:12417-12423.
33. Lowry, O. H., N. J. Rosebrough, A. L. Farr, and R. J. Randall. 1951. Protein measurement with the folin phenol reagent. J. Biol. Chem. 193-265-275.

34. Peikin, S. P., A. J. Rottman, S. Batzri, and J. D. Gardner. 1978. Kinetics of amylase release by dispersed acini prepared from guinea pig pancreas. Am. J. Physiol. 235:E743-E749.

35. Pondol, S. J., M. S. Schoeffield, G. Sachs, and S. Muallem. 1985. Role of free cytosolic calcium in secretagogue-stimulated amylase release from dispersed acini from guinea pig pancreas. J. Biol. Chem. 260:1008110086.

36. Rubin, R. P. 1984. Stimulation of inositol trisphosphate accumulation and amylase secretion by caerulein in pancreatic acini. J. Pharmacol. Exp. Ther. 231:623-627.

37. Powers, R. E., A. K. Saluja, M. J. Houlihan, and M. L. Steer. 1985. Inositol trisphosphate production and amylase secretion in mouse pancreatic acini. Biochem. Biophys. Res. Commun. 131:284-288.

38. Fisher, S. K., L. A. A. V. Rooijen, and B. W. Agranoff. 1984. Renewed interest in the polyphosphoinositides. Trends Biochem. Sci. 9: 53-56.

39. Wanke, M., W. Nagel, and F. Willis. 1966. Formen der experimentallen Pancreatitis patho-anatomisch gesehen. Frankf. Z. Pathol. 75: 207-212. 